\title{
Türkiye'deki Ilahiyat Fakültelerinde Din Sosyolojisi Alanında Tamamlanmış Lisansüstü Tezler Üzerine Bir Araştırma
}

\author{
IHSAN ÇAPCIOGLU \\ AR GÖR, ANKARA Ü. ILAHIYAT FAKÜLTESI \\ e-mail: icapci@divinity.ankara.edu.tr
}

\begin{abstract}
A Research on the Master and Ph.D Theses in the Sociology of Religion in Faculty of Divinities in Turkey. The scientific study of religion in the West began at the first quarter of the eighteenth century. During this time, numerous work on religion, especially sources of religion/religions had been published. However, history of sistematic and comparative study about the sociology of religion back to German sociologist Max Weber. Since his time, the scientific study of religion has also been carried out in Islamic and Turkish World. This paper introduces the works of master and ph.D theses are completed in all Turkish theological faculties since 1969. For this purpose, we used statistical data and analysis which are collected about master and ph. D. theses.
\end{abstract}

key words

Master and Ph.D Theses, Turkish Sociology of Religion, Sociology of Religion, Bibliography.

\section{Giriş}

Türkiye'deki İlahiyat Fakültelerinde ilk din sosyolojisi araşturmalan, 1949'da Ankara Üniversitesi Ilahiyat Fakültesi'nin kunulmasıyla birlikte başlamıs, bu alanda doktora düzeyinde ilk araşturma ise, 1969 yllında tamamlanmıstur. ${ }^{1} \mathrm{Bu}$ araşturmada, Ankara Üniversitesi Illahiyat Fakültesi'nin kuruluşundan günümüze kadar ülkemizdeki İlahiyat Fakültelerinde tamamlanmış yüksek lisans ve doktora tezlerinin ve bazı değişkenlere göre dağılımlannun tespiti amaç-

1 M. Rami Ayas'in 1966-1969 yllan arasında hazırladığ "Türkiye'de Ilk Tarikat Zümreleşmeleri Üzerine Din Sosyolojisi Af̧ısından Bir Araştırma" adl doktora tezinin değerlendirme jürisinde Ond. Prof. Dr. Hilmi Ziya Ülken, Prof. Dr. Mehmet Taplamacioğlu ve Prof. Dr. Neşet Cağatay yer almıstur. Araşturma bir giriş, iki bölüm ve sonuçtan oluşmaktadır. Girişte ana hatlanyla din sosyolojisi, din ve dini tecrübenin ifade șekilleri üzerinde durulmaktadır. Birinci bölüm, "Tarikat zümre ve zümreleşmelerinin toplumsal zemini olarak Anadolu'da Türk-Islam toplum çevresinin teşekkiilü ve öncesi” adırı taşımaktadır. ikinci bölümde Anadolu'da ilk dini-tasavvufi zümreleşmeler ele alınmaktadır. Araşturma tarihsel perspektifte Anadolu'nun dini-tasavvufi çeşitliliği üzerine yapılan genel bir değerlendirme ile sonuçlandırilmuşur. 
lanmıştır. Bu amaçla, öncelikle tespit edebildiğimiz 240 tezin hazırlandığ sosyal bilimler enstitüsü, danışmanı, ylı ve bibliyografik künyesi belirtilmiştir. Daha sonra, tezlerin fakültelere, tamamlandığ y1la ve türüne göre kategorik dağllman verilmiş, genel bir değerlendirmesi yapılmış ve önerilerde bulunulmuştur.

Tabio 1- Tezlerin Genel Dağıımı

\begin{tabular}{l|c|c}
\hline Uzmanlik Derecesi & N & $\%$ \\
\hline 1- Yüksek Lisans & 183 & $\% 75$ \\
\hline 2- Doksora & 57 & $\% 25$ \\
\hline Toplam & 240 & $\% 100$ \\
\hline
\end{tabular}

Tablo 1'de görüldü̈̆̈ü gibi 1969 yllndan bu tarafa ilahiyat fakültelerinde din sosyolojisi alanunda toplam 240 tez hazırlanmıstur. Bu tezlerin \% 75 'ten fazlası yüksek lisans; yaklaşık $\% 25^{\prime} \mathrm{i}$ ise doktora düzeyindeki araştırmalardan oluşmaktadır.

Tablo 2- Tezlerin Fakültelere Görc Dağilımı

\begin{tabular}{l|c|c}
\hline Sosyal Bilimler Enstitüsü & Yüksek Lisans & Doktora \\
\hline 1- Ankara Üniv. Sos. Bil. Ens. & 20 & 13 \\
\hline 2- Atatürk Üniv. Sos. Bil. Ens. & 9 & 6 \\
\hline 3- Cumburiyet Üniv. Sos. Bil E. & 1 & - \\
\hline 4- Dokuz Eyłül Üniv. Sos. Bil. E & 11 & 2 \\
\hline 5- Erciyes Üniv. Sos. Bil. Ens. & 31 & 10 \\
\hline 6- Inönü Üniv. Sos. Bil. Ens. & - & 1 \\
\hline 7- İstanbul Üniv. Sos. Bil. Ens. & 8 & 6 \\
\hline 8- Marmara Üniv. Sos. Bil Ens. & 31 & 4 \\
\hline 9- Ondokuz Mays Üniv. S.B.E & 8 & 2 \\
\hline 10- Sakarya Üniv. Sos. Bil. Ens. & - & 1 \\
\hline 11- Selçuk Üniv. Sos. Bil. Ens. & 33 & 9 \\
\hline 12- S. Demirel Üniv. Sos. Bil E. & 3 & - \\
\hline 13- Uludağ Üniv. Sos. Bil. Ens. & 24 & 3 \\
\hline 14 Yüzüncü Yll Üniv. Sos. B.E. & 4 & - \\
\hline Toplam & 183 & 57 \\
\hline
\end{tabular}

Tablo 2'de tezlerin din sosyolojisi bilim dalınun yüksek lisans ve doktora programlannı yürüten sosyal bilimler enstitülerine göre dağllmmlan verilmiştir. Buna göre, bünyesinde en fazla yüksek lisans tezi tamamlanan üç enstitü, Selçuk (33), Erciyes (31) ve Marmara (31)'dır. Aynca, yüksek lisans tezlerinin $\%$ 50'den fazlası bu üç enstitüde hazırlanmıştır. Bununla birlikte, en fazla doktora tezinin Ankara Üniversitesi Sosyal Bilimler Enstitüsü'nde tamamlandığı görülmektedir (13). Bunu sırasıyla Enciyes ve Selçuk Ǘniversitesi Sosyal Bilimler Enstituileri takip etmektedir. 
Tablo 3- Tezlerin Kategorik Dağıımı

\begin{tabular}{l|c|c}
\hline Tez Kategorisi & Yüksek Lisans & Doktora \\
\hline 1- Teorik & 109 & 27 \\
\hline 2- Ampirik & 74 & 30 \\
\hline Toplam & 183 & 57 \\
\hline
\end{tabular}

Tablo 3'te görüldüğü gibi, yüksek lisans düzeyindeki bilimsel çalş̧malann yaklaşık \% 65'i kuramsal din sosyolojisi araşturmasıdır. Doktora tezlerinde ise, ampirik çalışmaların ağırlığının kısmen daha fazla olduğu anlaşılmaktadır.

Tablo 4- Tczlerin Yıllara Göre Dağllımı

\begin{tabular}{l|c|c}
\hline Tez Ylu & Yüksek Lisans & Doktora \\
\hline $1-1969-1974$ & - & 1 \\
\hline $2-1975-1980$ & - & 1 \\
\hline $3-1981-1986$ & 1 & 4 \\
\hline $4-1987-1992$ & 20 & 11 \\
\hline $5-1993-1998$ & 87 & 18 \\
\hline $6-1999-2004$ & 76 & 23 \\
\hline Toplam & 183 & 57 \\
\hline
\end{tabular}

Tablo 4'te Din sosyolojisi tezlerinin yllara göre kategorik dağلlımı verilmiştir. Buna göre, 1990'dan sonra gerek yüksek lisans gerekse doktora tezlerinin sayısında periyodik bir artış yaşanmıştır. Aynca, tezlerin yıllara göre nicel artışında özellikle son on ylda huzl bir gelişme kaydedildiği görülmektedir.

Bu araştırmada yer alan yüksek lisans ve doktora tezlerinin belirlenmesinde, Yüksek Öğretim Kurulu Bilgi İşlem Merkezi Yayın ve Dokümantasyon Daire Başkanlığı Tezler Bölümü'nde kayth tezler arasından ilgili merkezde ve elektronik ortamda yapulan taramalar başta olmak üzere, Ankara Üniversitesi İlahiyat Fakültesi ve Sosyal Bilimler Enstitüsü ile Türkiye'deki diğer İlahiyat fakülteleri ve bağh bulunduklan sosyal bilimler enstitülerinin kütüphanelerindeki kaytlar esas kabul edilmiştir. Araştırma sonucunda tespit edebildiğimiz tezler aşağıda surasıyla; yazarlarının soyadı, adı, tezin adı, tamamlandığı sosyal bilimler enstitüsü, ylı ve danışmanına göre alfabetik olarak sıralanmıştur.

\section{a. Yüksek Lisans Tezleri}

- Abal, Nurullah. Said Nunside Mïslïman Hiristizan Dijalogumm Sosyolojzk Incelermesis Marmara Üniversitesi Sosyal Bilimler Enstitüsü, İstanbul 1995 [Dan: Doç. Dr. Yümni Sezen]. 
- Abuzer, Celil. GAP Bölgesi Harran Yöresinde Dirni we Sosjal Hajat (Ubade Aşireti Öme ği), Selçuk Üniversitesi Sosyal Bilimler Enstitüsü, Konya 1996 [Dan: Doç. Dr. Mehmet Bayyiğit].

- Acar, Ekrem. Sosjal Yapr ze Deği̧̧me Ekserande Alt Kültür. Üst Kültür Iliskisi, Marmara Üniversitesi Ortadoğu ve İslam Ülkeleri Enstitüsü, İstanbul 1999 [Dan: Doç. Dr. Zeki Arslantürk].

- Akbaş, Ömer Faruk. Bathllaşra ze Din 'Mibrap Dengisi Ömeği' 1923-1924, Selçuk Üniversitesi Sosyal Bilimler Enstitüsü, Konya 2001 [Dan: Yrd. Doç. Dr. Mehmet Akgül].

- Akça, Güsoy. Iptidai Karimlende Din A nlaysslan Teorileri ze Emile Dunkheim, Marmara Üniversitesi Ortadoğu ve İslam Ülkeleri Enstitüsü, İstanbul 1998 [Dan: Prof. Dr. Yümni Sezen].

- Akgül, Mehmet. Sanâjilesme ze Din: Sanâyilesme ue Din Illiskisinin Konja Organize Sanayi Bölgesinde Segilen Bir Ömek Grup Üzeninde A rasttrulmass, Selçuk Üniversitesi Sosyal Bilimler Enstitüsü, Konya 1991 [Dan: Yrd. Doç. Dr. Bünyamin Solmaz].

- Akkaya, Cevdet. A hmet Ceudet Pasa’nan Din ze Comjet Görüsü, Enciyes Üniversitesi Sosyal Bilimler Enstituisü, Kayseri 1992 [Dan: Prof. Dr. Ünver Günay].

- Aka, Ümit. Sanlunfa İlinde Diri Müessexelesme re Sosyal Fonksijonlan, Uludağ Üniversitesi Sosyal Bilimler Enstirüsü, Bursa 1997 [Dan: Prof. Dr. İzzet Er].

- Albayrak, Ali. Cengiz Aytmatorim Eserlerinde Eski Tïnk Dîn̂ Inandannm Tespiti ue Değedendirilmesi, Erciyes Üniversitesi Sosyal Bilimler Enstitüsü, Kayseri 1995 [Dan: Prof. Dr. Harun Güngör].

- Altukardeş, İsmet. Sosjologik A qudan İslâmida Horgörü İstanbul Üniversitesi Sosyal Bilimler Enstitüsü, İstanbul 1987 [Dan: Doç. Dr. Enis Öksüz].

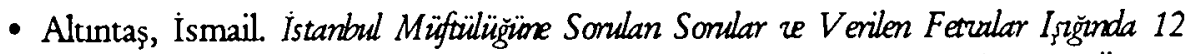
Ejlïl 1980'den Bu Yana Tünkize'de Dini Hajatin Sosjolöik A nalizi istanbul Ömeüi', Erciyes Üniversitesi Sosyal Bilimler Enstitüsü, Kayseri 1997 [Dan: Prof. Dr. Ünver Günay].

- Altundal, Ibrahim. Toplumsallasma Sünecinde Dinin Fonksijoms Ondokuz Mays Üniversitesi Sosyal Bilimler Enstitüsü, Samsun 1999 [Dan: Yrd. Doç. Dr. Erkan Perşembe].

- Aras, Cihat. Sosjal Statü Göstergesi Olarak Segh, Seyjid re Molla Kategorileni Van Gölü Çerresi Ömeği, Yüzüncü Yll Üniversitesi Sosyal Bilimler Enstitüsü, Van 2001 [Dan: Yrd. Doç. Dr. Necdet Subaşı].

- Arslan, Mustafa. Anaddu'rum Bir Tayra Illesindeki Irsanlann Dindarlkk Boyztlan Üze rine Sosyolojik Bir A rasttrma: Iskilip Ömeğh̆ Ondokuz Mays Üniversitesi Sosyal Bilimler Enstitüsü, Samsun 1997 [Yrd. Doç. Dr. Erkan Perşembe]. 
- Arslantürk, Hüseyin. Tünk Sosyolöi Taribinde Mebmet Izzet ze Yeri izstimaijat Derslen' Adli Eserinin Sosjolojik Degenendirmesi Marmara Üniversitesi Ortadoğu ve İslam Ülkeleri Enstitüsü, İstanbul 1999 [Dan: Prof. Dr. Zeki Arslantürk].

- Aucs, Muharrem. Zija Gökalp’e Göre 'Gelenek', Marmara Üniversitesi Ortadoğu ve İslam Ülkeleri Enstitüsü, İstanbul 1998 [Dan: Dr. Ali Coşkun].

- Avcr, Nazmi. Hilmi Zija Ülken'in Din Sosjolojisi A nlayzrs Enciyes Üniversitesi Sosyal Bilimler Enstitüsü, Kayseri 1993 [Dan: Prof. Dr. Ünver Günay].

- Ayata, Mehmet Kasım. Ardz̧ (Talas) Köyionde Sosjo-Kültürel Deģ̆̈me we Dini Hajat, Erciyes Üniversitesi Sosyal Bilimler Enstitüsü, Kayseri 2002 [Dan: Prof. Dr. Ünver Günay].

- Aydemir, Salih. Zija Gökalp'in Eserlerinde Din Sosydojissi Ankara Üniversitesi Sosyal Bilimler Enstitüsü, Ankara 1992 [Dan: Prof. Dr. Münir Koștaş].

- Aydunalp, Halii. Gerede'de Diru Haykat, Ankara Üniversitesi Sosyal Bilimler Enstituisü, Ankara 2003 [Dan: Prof. Dr. Münir Koştaş].

- Bağci, Osman. Yocgat ze Çeuresindeki Zijaret Yerleri Üzerine Tipalojik, Monfalojik ue Fenomendojik Bir A rasttrma, Erciyes Üniversitesi Sosyal Bilimler Enstituisü, Kayseri 1998 [Dan: Prof. Dr. Harun Güngör].

- Bağçıvan, Hasan Basri. Adana Dïziģi ilgesi Merkezindeki Ortä̈ğretim Kzmumlarnadaki

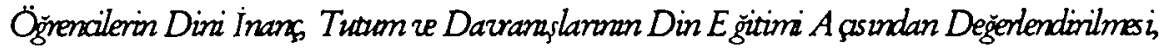
Selçuk Üniversitesi Sosyal Bilimler Enstitüsü, Konya 1996 [Dan: Yrd. Doç. Dr. Bünyamin Solmaz].

- Bakurc, Mustafa. İkinci Mesnatizet Dönemi İslamMeomuasmada Din Sosjolojisi Konularny la İlgili Tartusmalar, Marmara Üniversitesi Sosyal Bilimler Enstitüsü, İstanbul 2001 [Dan: Prof. Dr. Yümni Sezen].

- Banş, İsmail. Sosydojik Ag̣dan Beledijelerin Göneden Üzerine Bir Inceleme, İstanbul Üniversitesi Sosyal Bilimler Enstitüsü, İstanbul 1992 [Dan: Doç. Dr. Zekeriya Beyaz].

- Bayram, Menderes. Yakup Kadri Karaosmanoğlu'nda Din ze Aile, Uludağ Üniversitesi Sosyal Bilimler Enstituisui, Bursa 1999 [Dan: Yrd. Doç. Dr. Abdurrahman Kurt].

- Bıçakç̧, Ahmet. T. C. Dijanet Isjleri Baskkanliğ Din Issleri Yüksek Kumulu Kararlarman Sosjolojik A glan Incelenmesi (1946-1965 Yillan A ras2), Ankara Üniversitesi Sosyal Bilimler Enstitüsü, Ankara 1994 [Dan: Prof. Dr. Münir Koştaş].

- Bilgin, Meral. Tïnkije'de Sosyolöi Eğitimi ue Mimar Sinan Ünizersitesi Fen Edebrjat Fakültesi Sosjolöi Böliomü Monografisi Marmara Üniversitesi Ortadoğu ve İslam Ü1keleri Enstitüsü, İstanbul 1998 [Dan: Doç. Dr. Zeki Arslantürk]. 
- Bilgin, Vejdi. Sosyal Çäzulme Din Illijkilerine Din Sosydojisi A gsundan Kavramal Bir Yaklagrm, Ondokuz Mayss Üniversitesi Sosyal Bilimler Enstitüsü, Samsun 1996 [Dan: Yrd. Doç. Dr. Erkan Perşembe].

- Birekul, Mehmet. Sosyolojik A ądan İlk Dönem İslam Toplzamanda Kaden we A ile, Selçuk Üniversitesi Sosyal Bilimler Enstitüsü, Konya 2002 [Dan: Doç. Dr. Bünyamin Solmaz].

- Buyaci, Mehmet Yaşar. Yaşluarda Di̛ni Hajat, Atatürk Üniversitesi Sosyal Bilimler Enstitüsü, Erzurum 2002 [Dan: Prof. Dr. Niyazi Usta].

- Can, Ali. Zija Gökalp'te Fık b-Sosyoloji Iliskisi, Marmara Üniversitesi Sosyal Bilimler Enstitüsü, İstanbul 2002 [Dan: Prof. Dr. Yümni Sezen].

- Ceran, Ahmet Şeref. XIII. A srn Sosyal ze Kültönel Yapust İ̧inde Hz. Medlana'ran Yeri, Selçuk Üniversitesi Sosyal Bilimler Enstitüsü, Konya [Dan: Prof. Dr. Mehmet Aydın].

- Cinoğlu, Ekrem. Köy Dindarliğz-Adzzar Köjiönde Diri Hajat ze Dindarlık Ögütlen-, Yüzüncü Yll Üniversitesi Sosyal Bilimler Enstitüsü, Van 2002 [Dan: Yrd. Doç. Dr. Necdet Subaşı].

- Coşkun, Ali. Nâimầnn Din ze Cemżet Gönü̈üh Erciyes Üniversitesi Sosyal Bilimler Enstitüsü, Kayseri 1990 [Prof. Dr. Ünver Günay].

- Coşkun, Hasan. Sizas Illi Alturazala İlgesi Yassppmar ze Serimzanla Köjlerinde Alevilik, Erciyes Üniversitesi Sosyal Bilimler Enstitüsü, Kayseri 2001 [Dan: Prof. Dr. Ünver Günay].

- Çakar, Erdal. Hïseyin Kazum Kadrinnin Din ze Toplum Gönüleri, Uludağ Üniversitesi Sosyal Bilimler Enstitüsü, Bursa 1987 [Dan: Dr. İzzet Er].

- Çakmak, Muhammet. Dinâ Bir Grup Olarak A cimendälik, Ankara Üniversitesi Sosyal Bilimler Enstitüsü, Ankara 1997 [Dan: Prof. Dr. Münir Koştaş].

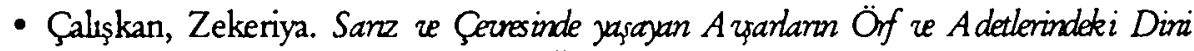
Unsumlarn Sosjolojik Tetkiki, Erciyes Üniversitesi Sosyal Bilimler Enstitüsü, Kayseri 1992 [Dan: Prof. Dr. Ünver Günay].

- Çanakçı, Kadir. Medlana'ran Toplum ze Dedlet Gönüsü, Uludağ Üniversitesi Sosyal Bilimler Enstitüsü, Bursa 1999 [Dan: Prof. Dr. İzzet Er].

- Çapcioğlu, Ihsan. Sosyal Değgisme Sünecinde Din ze Kadonn Toplumaal Koname Kastamonu Omeği-, Ankara Üniversitesi Sosyal Bilimler Enstitüsü, Ankara 2003 [Dan: Prof. Dr. Münir Koştaş].

- Çelik, Ahmet Dursun. Inegä'ion Inaną Coğrafjass, Uludağ Üniversitesi Sosyal Bilimler Enstitüsü, Bursa 2002 [Dan: Prof. Dr. İzzet Er].

- Çelik, Celaleddin. Kur'arida Toplunsal Değ̌rsme, Selçuk Üniversitesi Sosyal Bilimler Enstitüsü, Konya 1995 [Dan: Yrd. Doç. Mehmet Bayyjğit]. 
- Çelik, Günay. Pejami Safa'da Din ze Modernazm(Matmazel Noralja'nan Koltuğu Dokuzıncu Hariaje Koğusu ze Fatib-Harbije Romanlanna Göne), Uludağ Üniversitesi Sosyal Bilimler Enstitüsü, Bursa 1993 [Dan: Doç. Dr. İzzet Er].

- Çiçek, Dursun. Postmodemizmin İslamalar Üzerindeki Etkisi Tünkije Ömë̈i’, Erciyes Üniversitesi Sosyal Bilimler Enstitüsü, Kayseri 1996 [Dan: Prof. Dr. Ünver Günay].

- Çiftçi, Adil. Erol Giongör Üzerine Bir Monografi Denemesi Dokuz Eylül Üniversitesi Sosyal Bilimler Enstitüsü, İzmir 1989 [Dan: Doç. Dr. Erdoğan Furat].

- Çimen, Latife. 1923'ten Gionumzize Lise Sosyoloji Ders Kitaplan ze Sosyallestime Dizey leri Marmara Üniversitesi Ortadoğu ve İslam Ülkeleri Enstitüsü, İstanbul 1997 [Dan: Doç. Dr. Zeki Arslantürk].

- Dağh, Hatice. Din Sosyolojisinde Dini Gmuplarm Sumflandmalmash Dokuz Eylül Üniversitesi Sosyal Bilimler Enstitüsü, İzmir 2001 [Dan: Doç. Dr. M. Emin Köktaş].

- Delihasan, Abdullah. Kațp Çelebirnin Diri w Íçimai Görüsleri, Enciyes Üniversitesi Sosyal Bilimler Enstitüsü, Kayseri 1992 [Dan: Prof. Dr. Ünver Günay].

- Demir, Fatma. Tïnk Toplumonda Deģ̆sim ze Din: 'Erol Gümö̈r Ömeüg', Selçuk Üniversitesi Sosyal Bilimler Enstitüsü, Konya 2000 [Dan: Yrd. Doç. Dr. Mehmet Akgül].

- Demir, Veysel. Din Gönedilerinin Fonksijonlan ze Sosjo-Kültünd Tesirleri Üzerine Bir A rastoma 'Brnsa Ömeäg’', Uludağ Üniversitesi Sosyal Bilimler Enstitüsü, Bursa 1996 [Dan: Prof. Dr. İzzet Er].

- Demirci, Burhanetrin. Tünkine'de Çajgdas Dini Dönäsü̈mler (Bryan Wilson'zn Dinin Çăgdas Dönüstumleri Adll Eseri Bağlammanda), Dokuz Eylül Üniversitesi Sosyal Bilimler Enstitüsü, İzmir 2001 [Dan: Doç. Dr. M. Emin Köktaş].

- Demirci, Ömür. Telerizyonam Kültür Üzerindeki E tkileri, Marmara Üniversitesi Ortadoğu ve İslam Ülkeleri Enstitüsü, İstanbul 1999 [Dan: Doç. Dr. Zeki Arslantürk].

- Demirkan, Yaşar. Kentlesme Sünecinde Dini Yasam (E naman Ömeğ), Ankara Üniversitesi Sosyal Bilimler Enstitüsü, Ankara 2003 [Dan: Doç. Dr. Niyazi Akyüz].

- Dikmen, Alaattin. Elmallit Tefsinindeki Sosjolojkk Yaklașmlar, Uludağ Üniversitesi Sosyal Bilimler Enstituisü, Bursa 1995 [Dan: Prof. Dr. İzzet Er].

- Doğan, Metin. Kur'an'da Pexgamber-Toplum Illiskisi, Selçuk Üniversitesi Sosyal Bilimler Enstitüsü, Konya 1998 [Dan: Doç. Dr. Mehmet Bayyiğit].

- Doğan, Yusuf. Celal Num Illerinin Diri ze Ígtimai Hajata Bakz̧r, Ankara Üniversitesi Sosyal Bilimler Enstitüsü, Ankara 2003 [Dan: Prof. Dr. Münir Koştaş].

- Doğmus, Lokman. Tüntije'de XVII. Yïzyldaki Dini Çatzrmalara Sosyolojik Bir Bakus, Dokuz Eylül Üniversitesi Sosyal Bilimler Enstitüsü, İzmir 2002 [Dan: Prof. Dr. M. Rami Ayas]. 
- Durak, Hasan. Sabsinetin Ousromonda A ilenin Rolü Marmara Üniversitesi Sosyal Bilimler Enstirüsü, İstanbul 2001 [Dan: Prof. Dr. Yümni Sezen].

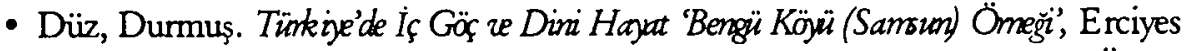
Üniversitesi Sosyal Bilimler Enstitüsü, Kayseri 1997 [Dan: Prof. Dr. Ünver Günay].

- Efe, Adem. Naksibendiliğmon Hâlidize Kolu re Mabma Sâmi Ramazanoğh Cemâati, Dokuz Eylül Üniversitesi Sosyal Bilimler Enstitüsü, İzmir 1994 [Dan: Prof. Dr. M. Rami Ayas].

- Eker, Ahmet. Kayseri ze Çeuresimde Nazar Inans ze Uygulamalan, Erciyes Üniversitesi Sosyal Bilimler Enstitüsü, Kayseri 2000 [Dan: Prof. Dr. Ünver Günay].

- Elmaz, Mehmet. Bir Dini Cemaat Lideri Olarak Mebmet Zabid Kotkuida Sosjolojik Yaklassmlar, Uludağ Üniversitesi Sosyal Bilimler Enstitüsü, Bursa 1997 [Dan: Prof. Dr. İzet Er].

- Emer, Yener. Numettin Topsinmon Din we Dedet A nlayzss Uludağ Üniversitesi Sosyal Bilimler Enstitüsü, Bursa 1991 [Dan: Doç. Dr. İzzet Er].

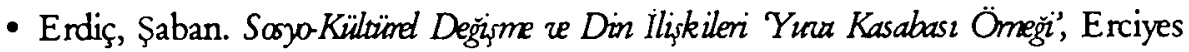
Üniversitesi Sosyal Bilimler Enstitüsü, Kayseri 2001 [Dan: Doç. Dr. Abdulvahap Taştan].

- Erdinç, Yasemin. Zija Gökalp'te Millet Karrama ue Milletlesme Sïneci, Marmara Üniversitesi Sosyal Bilimler Enstitüsü, İstanbul 2000 [Dan: Prof. Dr. Zeki Arslantürk].

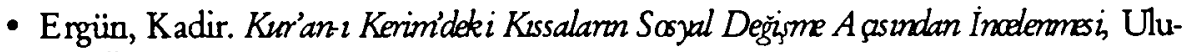
dağ Üniversitesi Sosyal Bilimler Enstitüsü, Bursa 1992 [Dan: Doç. Dr. Izzet Er].

- Eren, Selim. Günumiezde Sorular ze Ceuaplarn Isığnda Diri Hajata Sosyolojik Bir Yaklasrm, Ankara Üniversitesi Sosyal Bilimler Enstitüsü, Ankara 1994 [Dan: Prof. Dr. Münir Koştaş].

- Erkan, Sevim. Toplumsal Deģ̆̈meler karşsinda Taur Belintemede Dina Gmoplar 'Fethullah Gülen Cemaati, Ondokuz Mayss Üniversitesi Sosyal Bilimler Enstitüsü, Samsun 1995 [Dan: Yrd. Doç. Dr. Erkan Perşembe].

- Erten, Hayri. Din Sasyolojisi A gssından Hz. Ömer Dönemi ze Olajlan, Selçuk Üniversitesi Sosyal Bilimler Enstitüsü, Konya 1995 [Dan: Yrd. Doç. Dr. Bünyamin Solmaz].

- Eyice, Berrin. Frarszz Sosyoloğu Gabriel Le Bras'da Din Sasydojisi, Selçuk Üniversitesi Sosyal Bilimler Enstitüsü, Konya 1988 [Dan: Prof. Dr. Mehmet Aydın].

- Eyüpoğlu, Osman. Samsın Illi Kügük Sanaji Sitesinin Sosjo-Ekonomik Yapist İginde Dinin Komumu, Ondokuz Mayss Üniversitesi Sosyal Bilimler Enstitüsü, Samsun 1996 [Dan: Yrd. Doç. Dr. Erkan Perşembe]. 
- Ezerbolatoğlu, Ulviye. Iletisimin Kitlesel Etkisi Bağlamanda Tünkije'de Basmm Dine Bakısz, Ondokuz Mayss Üniversitesi Sosyal Bilimler Enstitüsü, Samsun 1996 [Dan: Yrd. Doç. Dr. Erkan Perşembe].

- Farkhadov, Ali. Azerbaycan Tünklerinan Etrik Kimliğinin Ousumu, Marmara Üniversitesi Ortadoğu ve İslam Ülkeleri Enstitüsü, İstanbul 1998 [Dan: Dr. Ali Coşkun].

- Fazloğlu, Emel. Basnak Kimliğinin Olustomu Marmara Üniversitesi Ortadoğu ve İslam Ülkeleri Enstitüsü, İstanbul 1999 [Dan: Dr. Ali Coşkun].

- Gasimova, Mihriban. A zerbaycan'da Dini Hayat 'Bakü Ömeği', Ankara Üniversitesi Sosyal Bilimler Enstitüsü, Ankara 1999 [Dan: Yrd. Doç. Dr. Niyazi Akyüz].

- Gedikli, Yaşar. Modemlesme Din Ilijkileri ue Modemlesmenin İslâm Toplumma Girnis Sïreci, Ondokuz Mayss Üniversitesi Sosyal Bilimler Enstitüsü, Samsun 1996 [Dan: Yrd. Doç. Dr. Erkan Perşembe].

- Gözel, Halil. Demokratik Sistemde Baskı Gouplam, Marmara Üniversitesi Ortadoğu ve İslam Ülkeleri Enstitüsü, İstanbul 1998 [Dan: Prof. Dr. Yümni Sezen].

- Güçlü, Nuray Savc1. Naimaja Göre XVIII. Yüzyll Osmanli Iktisadi Yapzsz ze Toplum sal Somudar, Marmara Üniversitesi Ortadoğu ve İslam Ülkeleri Enstitüsü, İstanbul 1998 [Dan: Doç. Dr. Zeki Arslantürk].

- Güllü, İsmail. Almama'daki III. Kusak Tïk Genderinin Dirn Tutum ze Daurarajlan Käln Ömeği, Erciyes Üniversitesi Sosyal Bilimler Enstitüsü, Kayseri 2002.

- Günaydın, Mustafa. Pejami Safánn Romanlarnada Din re A ile, Selçuk Üniversitesi Sosyal Bilimler Enstituisü, Konya 2000 [Dan: Doç. Dr. Mehmet Bayyiğit].

- Güngör, Özcan. Modernizm Sïnecinde Cami Cemaatinin Din A nlayz̧r Ankara Üniversitesi Sosyal Bilimler Enstitüsü, Ankara 2004 [Dan: Doç. Dr. Niyazi Akyüz].

- Güngör, Recep Kemal. Ekonomi we A le Üzerine Görüsleri Ile Tabir Çağatays Süleyman Demirel Üniversitesi Sosyal Bilimler Enstitüsü, Isparta 1997 [Dan: Yrd. Doç. Dr. Ahmet Yllmaz Soyyer].

- Gürsoy, Şahin. Milli Kimlig̈̈n Ouszomenda Dinin Rdü, Atatürk Üniversitesi Sosyal Bilimler Enstitüsü, Erzurum 1996 [Dan: Yrd. Doç. Dr. Niyazi Usta].

- Hocaoğullan, Emine. Sosjal Tabakalaagma ze İslamida Kölelik, Uludağ Üniversitesi Sosyal Bilimler Enstitüsü, Bursa 2002 [Dan: Prof. Dr. İzzet Er].

- Huca, Seyfettin. Din Sosjolojisi A ģsmadan İsrailogúllannan Misr Dönemi, Selçuk Üniversitesi Sosyal Bilimler Enstitüsü, Konya 1995 [Dan: Yrd. Doç. Dr. Bünyamin Solmaz].

- Işçı, Uğur. Köy Gendiği ze Din 'Küpeli Köyü (Özratan/Kayseri) Ömek Oayz Üzerine Soyylojik Bir A rastrma, Erciyes Üniversitesi Sosyal Bilimler Enstitüsü, Kayseri 1993 [Dan: Prof. Dr. Ünver Günay]. 
- İçer, Osman. Tünkije'de Demokrasije Gesis Sïreci Üzerine Bir Inceleme, İstanbul Üniversitesi Sosyal Bilimler Enstitüsü, İstanbul 1999 [Dan: Prof. Dr. Zekeriya Beyaz].

- İnceler, Halime. İslamjetteki Șekilsellesmenin Soxjal Bütümlesmeje E tkisi, İstanbul Üniversitesi Sosyal Bilimler Enstitüsü, İstanbul 1990 [Dan: Prof. Dr. Amiran Kurtkan Bilgiseven].

- Kaban, Engin. Hasan Rami Efendi ze Çaykara Sosjo Kültïnel Hajatuna Etkileri, Uludağ Üniversitesi Sosyal Bilimler Enstitüsü, Bursa 1997 [Dan: Prof. Dr. İzzet Er].

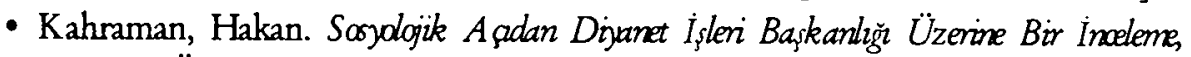
İstanbul Üniversitesi Sosyal Bilimler Enstitüsü, İstanbul 1993 [Dan: Doç. Dr. Zekeriya Beyaz].

- Kara, Zülküf. Modem Tünk Sosjolöi Literatïrände Osmanli Dinsellig̈, Yüzüncü Yl Üniversitesi Sosyal Bilimler Enstitüsü, Van 2002 [Dan: Yrd. Doç. Dr. Necdet Subaşı].

- Karabacak, Mustafa. Halim Sabit Şibay'da Din Sosyolojisi, Süleyman Demirel Üniversitesi Sosyal Bilimler Enstitüsü, Isparta 2001 [Dan: Yrd. Doç. Dr. A. Yllmaz Soyyer].

- Karaman, Kasım. Gömen Uygularnn Dini Yasayslan Üzerine Sosjolojik Bir A rastrma 'Kasseri Ömeği', Erciyes Üniversitesi Sosyal Bilimler Enstitüsü, Kayseri 1995 [Dan: Prof. Dr. Ünver Günay].

- Karaman, Mustafa. Afjon Salar Kasabasinda Toplurrsal Hareketlilik, Değ̆sim ze Dini Hayat Üzerine Sosjolojik Bir Inceleme, Enciyes Üniversitesi Sosyal Bilimler Enstitüsü, Kayseri 2000 [Dan: Prof. Dr. Ünver Günay].

- Karaşahin, Hakkı. es-Seyjid Osman Hulìsi Efendi'nin Tasaurufí Görüsleri ze Hâlidâ Cemâati, Enciyes Üniversitesi Sosyal Bilimler Enstitüsü, Kayseri 1998 [Dan: Prof. Dr. Ünver Günay].

- Karataş, Gülşen. İslam Medenzetinin Taribsel Gelizirimi ze İslam Dïnzasumen Meseleleri Hakkunda Malik Bin Nebinin Görǚlleri Marmara Üniversitesi Ortadoğu ve İslam Ülkeleri Enstitüsü, İstanbul 1998 [Dan: Doç. Dr. Zeki Arslantürk].

- Kayacan, Murat. Diri Gnuplara Ginjs ze Çıkus Motizleri (Dini Gmolara Giren Bineyler Üzeninde Sosjal Psikdojik Bir A rastrma), Uludağ Üniversitesi Sosyal Bilimler Enstitüsü, Bursa 2002 [Dan: Prof. Dr. Hayati Hökelekli].

- Kertiş, Necati. Kastamomu Yatrlannon Sosyal Bïtiölesme A gssmdan Bälge Halkz Üzerin deki Tesirleri, Marmara Üniversitesi Ortadoğu ve İslam Ülkeleri Enstitüsü, İstanbul 1999 [Dan: Prof. Dr. Zeki Arslantürk].

- Keskin, İbrahim. Zibmizet ze Darrams Iliskisi Agssundan Kurianz Kerimide Insan Tipolojileri, Uludağ Üniversitesi Sosyal Bilimler Enstitüsü, Bursa 1999 [Dan: Prof. Dr. İzzet Er]. 
- Keskin, Yahya Mustafa. Trabzon İli Inanç Coğrafjast, Enciyes Üniversitesi Sosyal Bilimler Enstitüsü, Kayseri 1995 [Dan: Prof. Dr. Ünver Günay].

- Kulıç, Ahmet Fanuk M. Akkf Ersoy'ron Din ze Toplum A nlazyş Marmara Üniversitesi Sosyal Bilimler Enstitüsü, İstanbul 1995 [Dan: Doç. Dr. Yümni Sezen].

- Kurboğa, Ziyaeddin. Dini Gruplar Sosydojisi A gsumdan ilk Dönem Aleri Dürriznesinin Tesekkülï, Konya 1999 [Dan: Yrd. Doç. Dr. Mehmet Akgül].

- Kurml, Mehmet. Almanza'da Dijunet İlleri Tünk Islam Birliğine (D.I.T.I.B) Bağle Camilende Çalisan Din Göredileninin Sommlan 'Kızey Ren Westfalen Ömeüz', Selçuk Üniversitesi Sosyal Bilimler Enstitüsü, Konya 1997 [Dan: Doç. Dr. Bünyamin Solmaz].

- Kurtepe, Selçuk, Din «e Liberalizm Atatürk Üniversitesi Sosyal Bilimler Enstitüsü, Erzurum 2002 [Dan: Prof. Dr. Niyazi Usta].

- Kiraz, Nuri. Tünkine'de 1980 Sorrası Yeri Diüsimce Akumlan ze Din (Sirul Toplum, Ikina Mesnatijet, Neo-Ormanlzallk ze Cedit Grubu Ömeği), Selçuk Üniversitesi Sosyal Bilimler Enstitüsü, Konya [Dan: Yrd. Doç. Dr. Mehmet Bayyiğit].

- Kirman, Mehmet Ali. Yeri Yayla'da Diri Hajat, Ankara Üniversitesi Sosyal Bilimler Enstitüsü, Ankara 1994 [Dan: Prof. Dr. Münir Koştaş].

- Koç, Alparslan. Sosyal Bütionlesme ze Din Illiskisi, Ondokuz Mays Üniversitesi Sosyal Bilimler Enstitüsü, Samsun 2001 [Dan: Yrd. Doç. Dr. Erkan Perşembe].

- Kodaz, Tevfik. Onzantalizm re Din 'Islam Ömę̆i', Selçuk Üniversitesi Sosyal Bilimler Enstitüsü, Konya 1995 [Dan: Yrd. Doç. Dr. Bünyamin Solmaz].

- Korkmaz, Hüseyin. Sait Halim Paşa'nan Dini ze Ị̇timai Gönüsleri, Erciyes Üniversitesi Sosyal Bilimler Enstitüsü, Kayseri 1994 [Dan: Prof. Dr. Ünver Günay].

- Korkmaz, Nurettin. Ibn Haldsarida Sosydojik Karramlar, Marmara Üniversitesi Sosyal Bilimler Enstitüsü, İstanbul 1995 [Dan: Doç. Dr. Zeki Arslantürk].

- Kömürcioğlu, Ahmet. Kur'arida Had Cezalannan Sosyolojik Tablili, Uludağ Üniversitesi Sosyal Bilimler Enstitüsü, Bursa 1999 [Dan: Yrd. Doç. Dr. Abdurrahman Kurt].

- Kurt, Abdurrahman. İlâmin Illk Döneminde Â ile Müessesesi, Sosyolojik Bir Yaklașum, Uludağ Üniversitesi Sosyal Bilimler Enstitüsü, Bursa 1987 [Dan: Dr. İzzet Er].

- Kuru, Necip Fazıl. Menzil Naksiliği Merkez Cemaati Üzerine Sosjolojik Bir A rastrma, Erciyes Üniversitesi Sosyal Bilimler Enstitüsü, Kayseri 1999 [Dan: Prof. Dr. Ünver Günay].

- Külünk, Hasan. Yönetim Teorileri A gsindan Özel Hastanelende Yönetion Davranuslan, Marmara Üniversitesi Ortadoğu ve İlam Ülkeleri Enstitüsü, İstanbul 1999 [Dan: Prof. Dr. Zeki Arslantürk]. 
- Macit, Mustafa. Halken Din Çergezesinde Beklentileri (Enzumon Otu Ömeğ), Atatürk Üniversitesi Sosyal Bilimler Enstitüsiu, Erzurum 2001 [Dan: Doç. Dr. Niyazi Usta].

- Murzabaev, Mametbek. Krgzzistarida Dini Hajat ( $O_{\xi}$ Ömeği), Ankara Üniversitesi Sosyal Bilimler Enstitüsü, Ankara 2003 [Dan: Prof. Dr. Münir Koştaş].

- Musaoğlu, Ebru. Dini Tecrïbe Gelisimine Sosjal Ögreme Kuram A ģsından Bir Yaklašm, Dokuz Eyłül Üniversitesi Sosyal Bilimler Enstitüsü, İzmir 2002 [Dan: Prof. Dr. Recep Yaparel].

- Nar, Çetin. S. A bmet A ruasinin Sosjalojik Görüslerinde Dini ue Mali Unsumar, Marmara Üniversitesi Sosyal Bilimler Enstitüsü, İstanbul 1996 [Dan: Doç. Dr. Yümni Sezen].

- Neziri, Reyhan. Kalkandelen $x$ Çerresinde Dini $x$ Sosjal Hajat, Uludağ Üniversitesi Sosyal Bilimler Enstitïsü, Bursa 2000 [Dan: Prof. Dr. İzet Er].

- Oğrak, Abdülkadir. Türk Basmanda Din-Toplum Ilişkileri (1980-1990), Atatürk Üniversitesi Sosyal Bilimler Enstitüsü, Erzunum 1994 [Dan: Doç. Dr. Hüsnü Ezber Bodur].

- Okumuş, Ejder. Kıơ'an'da Toplumral Çöküsü̈n Nedenderi, Selçuk Üniversitesi Sosyal Bilimler Enstitüsü, Konya 1995 [Dan: Yrd. Doç. Dr. Mehmet Bayyiğit].

- Öz, Nedim. Ilgrn'm Tekke Köjündeki Maneri Halk Inandarma Sosyolojik Bir Yaklasm. Selçuk Üniversitesi Sosyal Bilimler Enstitüsü, Konya 1995 [Dan: Prof. Dr. Mehmet Aydin].

- Özcan, Recep. Mebmet Akifde Sosyal Problemlerimiz u Çäzüm Yollan, Selçuk Üniversitesi Sosyal Bilimler Enstitüsü, Konya 1994 [Dan: Yrd. Doç. Dr. Mehmet Bayyiğit].

- Özdemir, Selma. Abmet Hardi Tanpmar'm Eserlerinde Dirni Temalar, Uludağ Üniversitesi Sosyal Bilimler Enstitüsü, Bursa 1997 [Dan: Prof. Dr. İzzet Er].

- Özdemirkap, Muhammet. Tühk Sosjologlannan Din Görüsleri /Omban Tünkdojan Öme ğ), Marmara Üniversitesi Sosyal Bilimler Enstitüsü, İstanbul 1996 [Dan: Doç. Dr. Zeki Arslantürk].

- Özensel, Ertan. Kentlilesemejen A ilederin Sasjo-Kültünd ze Ekonomik Kökenine Dair Sosjolojik Bir A rassturma, Selçuk Üniversitesi Sosyal Bilimler Enstitüsü, Konya 1992 [Dan: Prof. Dr. Mehmet Aydun].

- Özer, Kamil. Zija Gökalp Sosolojisinde Íslamaluk ue Modernizm Dokuz Eylül Üniversitesi Sosyal Bilimler Enstitüsü, İzmir 1995 [Dan: Yrd. Doç. Dr. M. Emin Köktaş].

- Özler, İbrahim. Comil Merif̧'te Ayden Problems, Atatürk Üniversitesi Sosyal Bilimler Enstitüsü, Erzunum 2000 [Dan: Doç. Dr. Niyazi Usta]. 
- Öztürk, Coşkun. Cumbumjete Geçis Süreci ue Tïnk Romanlanma Göre Sosyal Değzime Ogusu 'A bmet Hamdi Tanqunar Ömĕgi' (1901-1962), Marmara Üniversitesi Ortadoğu ve İslam Ülkeleri Enstituisü, İstanbul 1998 [Dan: Dr. Ali Coşkun].

- Öztürk, Ali İhsan. İed Il Merkezi’nin Inanç Cografjast Erciyes Üniversitesi Sosyal Bilimler Enstitüsü, Kayseri 1996 [Dan: Prof. Dr. Şaban Kuzgun].

- Özüdoğru, Halide Nur. Imam Hatip Lisesi Ögrencilerinin Dini Inanç ze Tuturran Ille Sosyo-Kültiönd Beklenti we Sonudan 'Koma Ömeği', Selçuk Üniversitesi Sosyal Bilimler Enstituisü, Konya [Dan: Doç. Dr. Mehmet Bayyiğit].

- Pajaziti, Ali. Gegis Sürecinde Makedoma Ürizersite Gendiği we Din Olgusu Marmara Üniversitesi Sosyal Bilimler Enstitüsü, İstanbul 1998 [Dan: Doç. Dr. Zeki Arslantïrk].

- Pala, Fatma Nur. Liseli Kzlann Sosyalizasyon Sïrecine Katulmian (İstanbul'daki Liseli Kzz Ö̈rnaler Üzerine Bir Inceleme), Marmara Üniversitesi Sosyal Bilimler Enstitüsü, İstanbul 1999 [Dan: Dr. Ali Coşkun].

- Polat, Fazl. Dijanet Issleri Baskkanliğr Cerçeresinde Din Toplum Illiskisine Bir Bakus (19801990), Atatürk Üniversitesi Sosyal Bilimler Enstitüsü, Erzunum 1996 [Dan: Yrd. Doç. Dr. Niyazi Usta].

- Saçıntı, Ahmet. Kzr'arida İdeal Toplum Uludağ Üniversitesi Sosyal Bilimler Enstitüsü, Bursa 2001 [Dan: Yrd. Doç. Dr. Abdurrahman Kurt].

- San, Süleyman Arif. A bmet Rzza'rnn Sosyolojik w Diri Görüsleri, Ankara Üniversitesi Sosyal Bilimler Enstitüsü, Ankara 2004 [Dan: Doç. Dr. Niyazi Akyüz].

- Savc1, Nural. Islam Filozoflaranda Bülim Sunafaması ze Sosyolöi A nlayzs, Marmara Üniversitesi Ortadoğu ve İslam Ülkeleri Enstituisü, İstanbul 1998 [Dan: Doç. Dr. Zeki Arslantiük].

- Savc1, Sunay Delilbaşı. Kïrtlerin Etrik Kökenleri İle İlgili Teoriler, Marmara Üniversitesi Ortadoğu ve İslam Ülkeleri Enstitüsü, İstanbul 1998 [Dan: Doç. Dr. Zeki Arslantürk].

- Serin, Mustafa. Serif Mardin w Din Sosjolojisi, Erciyes Üniversitesi Sosyal Bilimler Enstitüsü, Kayseri 1998 [Dan: Prof. Dr. Ünver Günay].

- Shauyenov, Didar. Güoümzäze Kazakistan'da Dini Yasayzs (Gümey Kazakistan Ömeg̈i), Ankara Üniversitesi Sosyal Bilimler Enstitüsü, Ankara 2002 [Dan: Prof. Dr. Münir Koştaş].

- Sinanoğlu, A. Faruk. Darende Illgesi Kasaba u Kölerinde Dini Hayat, Atatürk Üniversitesi Sosyal Bilimler Enstitüsü, Erzunum 1995 [Dan: Prof. Dr. Hüsnü Ezber Bodur]. 
- Sofuoğlu, Nulgün. Taloot Parsons'zn Yapisal-İjlessel Kuram we Din Dokuz Eylül Üniversitesi Sosyal Bilimler Enstitüsü, İzmir 2001 [Dan: Doç. Dr. M. Emin Köktaş].

- Solihat, Ade. Endonezja'da Ünizersite Ögrenci Hareketlerinin Sosyolöik Analizi '1998 Y zl Ömeği, Marmara Üniversitesi Ortadoğu ve İslam Ülkeleri Enstitüsü, İstanbul 2000 [Dan: Prof. Dr. Zeki Arslantürk].

- Suleymanov, Abülfez. Azerbajcarida Orta dereedi Okullanda Tarib Ö̈retimi ze Ë̈̈tminde Sogyet Ideolojisinin Etkisi, İstanbul Üniversitesi Sosyal Bilimler Enstitüsü, İstanbul 1998 [Dan: Doç. Dr. Zekeriya Beyaz].

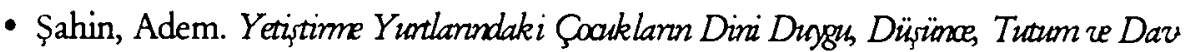
ramaslan Üzerine Bir A rașttrma, Selçuk Üniversitesi Sosyal Bilimler Enstitüsü, Konya 1993 [Dan: Yrd. Doç. Dr. Bünyamin Solmaz].

- Şahin, İlkay. Gelenek ue Değģim A gssmdan Kadenlann Diri Yasantulam, Tutum ue Davranaslan -Boğazlyan Ömë̈i-, Erciyes Üniversitesi Sosyal Bilimler Enstitüsü, Kayseri 2002 [Dan: Prof. Dr. Ünver Günay].

- Şenay, Bülent. Dini Cemaatler Sosyolojisi ze Hristizan Comaatleri Uludağ Üniversitesi Sosyal Bilimler Enstitüsü, Bursa 1991 [Dan: Doç. Dr. İzzet Er].

- Şenlik, Mehmet. Sait Halim Paşa'da Din-Dezlet İliskisi, Uludağ Üniversitesi Sosyal Bilimler Enstitüsü, Bursa 1998 [Dan: Prof. Dr. İzzet Er].

- Simşek, Hacı Ahmet. İslamida Zekat Müessesesine Sosyolojik Bir Yaklasım Selçuk Üniversitesi Sosyal Bilimler Enstitüsü, Konya 1994 [Dan: Prof. Dr. Mehmet Aydin].

- Şişik, Cemile Zehra. Bolradin ze Çerresinde Sosyal ue Diri Hajat, Selçuk Üniversitesi Sosyal Bilimler Enstitüsü, Konya 2002 [Dan: Doç. Dr. Bünyamin Solmaz].

- Şulul, Halit. Gïmesdoğu Raporlannda Din Unsumu Uludağ Üniversitesi Sosyal Bilimler Enstitüsü, Bursa 2000 [Dan: Prof. Dr. İzzet Er].

- Taş, Kemalettin. Comil Meriçin Din ze Topluma Bakz̧̧ Ankara Üniversitesi Sosyal Bilimler Enstitüsü, Ankara 1997 [Dan: Prof. Dr. Münir Koştaş].

- Taşçeken, Mehmet. Tünkijéde Dedet Tabrilleri Politikast ze Planlı Dönemde Kamu Gelirleri İgindeki Pays İstanbul Üniversitesi Sosyal Bilimler Enstitüsü, İstanbul 1991 [Dan: Doç. Dr. Zekeriya Beyaz].

- Taşğın, Ahmet. Ereğli ze Çevresindeki A levilerde Dirni ue Sosjal Hajat, Selçuk Üniversitesi Sosyal Bilimler Enstitüsü, Konya 1997 [Dan: Doç. Dr. Bünyamin Solmaz].

- Taştan, Abdulvahap. Nesturi Misyonerlerin Orta A sya ue Cerresindeki Faalizetleri, Erciyes Üniversitesi Sosyal Bilimler Enstitüsü, Kayseri 1986 [Dan: Prof. Dr. Ünver Günay]. 
- Tatllioğlu, Durmuş. Din Göredilerinin Soxjo-Ekonomik Yapulanna Sosyolojik Bir Bakuss (Sizas Ili Ömeğ), Cumhuriyet Üniversitesi Sosyal Bilimler Enstitüsü, Sivas 1989 [Dan: Prof. Dr. Ylldıray Arsan].

- Tekin, Hatice Vicdan. Çumra'da Sosyal ve Dini Hayat, Selçuk Üniversitesi Sosyal Bilimler Enstitüsü, Konya 1997 [Dan: Doç. Dr. Bünyamin Solmaz].

- Tekin, Mustafa. Merlana Celaleddinzi Rumi'de Din ze Toplum Selçuk Üniversitesi Sosyal Bilimler Enstitüsü, Konya 1995 [Dan: Yrd. Doç. Dr. Bünyamin Solmaz].

- Toker, İhsan. 1940'l Yullar Sorrasz Tïnk Sosjolojisinde Din Temasu, Ankara Üniversitesi Sosyal Bilimler Enstitüsü, Ankara 1999 [Dan: Prof. Dr. Münir Koştaş].

- 'Tombul, Abdurrahman. Altmäzüon'de Dini ze Sosjal Hayat, Uludağ Üniversitesi Sosyal Bilimler Enstitüsü, Bursa 1995 [Dan: Prof. Dr. İzzet Er].

- Tuğrul, Süleyman. Felsefe ze Iģtimaizat Meomuasinan (1927-1930) Tiank Toplumbilimin deki Yeri, Dokuz Eylül Üniversitesi İlahiyat Fakültesi, İzmir 2002 [Dan: Prof. Dr. M. Rami Ayas].

- Turhan, Faruk Tühkije'de Sağ ze Muhafazakarlkk 'Ali Fuat Bajgil Ömĕ̆', Selçuk Üniversitesi Sosyal Bilimler Enstitüsü, Konya [Dan: Yrd. Doç. Dr. Mehmet Akgül].

- Uçar, Ramazan. Abdullab Ceudet'te Din ze Batullaşma, Ankara Üniversitesi Sosyal Bilimler Enstitüsü, Ankara 1997, [Dan: Prof. Dr. Münir Koştaş].

- Ülver, Lütfü. Peter L. Bergerin Sosyoloji A nlayzsina Göre Modem Toplumda Din Sornoma Dokuz Eylül Üniversitesi Sosyal Bilimler Enstitüsü, İzmir 2002 [Dan: Prof. Dr. M. Emin Köktaş].

- Ünal, Ahmet Zeki. Dirselližin Dönüsümü Bağlamnda Laiklik ue Sekülerlik -Modem Tïnkije Ömeği-, Yüzüncü Yll Üniversitesi Sosyal Bilimler Enstitüsü, Van 1997 [Dan: Doç. Dr. Ahmet Bilgili].

- Ünal, Ali. Sosydojik A ̧̧dan Dinler A rası Dijalog Atatürk Üniversitesi Sosyal Bilimler Enstitüsü, Erzurum 2002 [Dan: Prof. Dr. Niyazi Usta].

- Ünal, Mahir. Prof. Dr. Nihat Nimmizn Haxath, Eserleri ze Sosyolojik Görülleri Üzerine Bir Inceleme, İstanbul Üniversitesi Sosyal Bilimler Enstitüsü, İstanbul 1997 [Dan: Doç. Dr. Zekeriya Beyaz].

- Ünal, Mehmet Süheyl. Mistik Tecrübe Ölgeğinnin Güreriarlik ze Gegerlik Çallsmasu, Dokuz Eyłül Üniversitesi Sosyal Bilimler Enstitüsü, İzmir 2000 [Dan: Doç. Dr. Recep Yaparel].

- Ünsür, Muhammet Ali. Danca Beldesinde Deprem Öncesi ze Sonrası Dira ze Saxjal Hayat, Ankara Üniversitesi Sosyal Bilimler Enstitüsü, Ankara 2003 [Dan: Prof. Dr. Münir Koștaş]. 
- Ünal, Vehbi. Nurettin Topçu'nun Sosyolojik Görüşlerinde Dini Unsurlar, Marmara Üniversitesi Ortadoğu ve İslam Ülkeleri Enstituisü, İstanbul 1996 [Dan: Doç. Dr. Zeki Arslantürk].

- Yalçın, Abdurrahim. İrsan Davraraslan ue Din (Psiko-Sasłal Bir A naliz), Selçuk Üniversitesi Sosyal Bilimler Enstitüsü, Konya 1996 [Dan: Doç. Dr. Mehmet Bayyiğit].

- Yavuz, Sefer. Sabri F. Ülgener’e Göre Diñ İktisât Ablâkı Ilişkisi, Ankara Üniversitesi Sosyal Bilimler Enstitüsü, Ankara 2002 [Dan: Doç. Dr. Niyazi Akyüz].

- Yavuz, Şaban. Lise Ögrencilerinin Dini Inanc Tutum ze Davraraslan Üzerine Bir A rasttr. ma Selçuk Üniversitesi Sosyal Bilimler Enstitüsü, Konya 2001 [Dan: Doç. Dr. Mehmet Bayyiğit].

- Yavuzer, Hasan. Haabektaș Yönesi Bektasi Inandannan Din Sosydojisi Yönïnden Inaca lenmesi, Enciyes Üniversitesi Sosyal Bilimler Enstitüsü, Kayseri 1993 [Dan: Prof. Dr. Ünver Günay].

- Yayan, Abdurrahman. Dini Gmuplann ze Hareketerin Sosjolojisi 'Yabjalı Ömeği', Erciyes Üniversitesi Sosyal Bilimler Enstitüsü, Kayseri 1992 [Dan: Prof. Dr. Ünver Günay].

- Yaylah, Hüseyin. Hz. Mubammed Dönemindeki Fitne Hadiselerine Sosyolojik Bir Yaklasım Selçuk Üniversitesi Sosyal Bilimler Enstituisü, Konya 1995 [Dan: Yrd. Doç. Dr. Bünyamin Solmaz].

- Yazgan, Tahsin. Çağdas Tïnk Sosjologlannda Din ze Toplum Erd Güngör Ömeği', Marmara Üniversitesi Sosyal Bilimler Enstitüsü, İstanbul 1996 [Dan: Doç. Dr. Zeki Arslantürk].

- Yildız, Köksal. Ondu Ili Perşembe Illesine Bağll Doğanköy'deki Dini Hayat Üzerine Sosjo lojik Bir A rastrma, Erciyes Üniversitesi Sosyal Bilimler Enstitüsü, Kayseri 2002 [Dan: Prof. Dr. Ünver Günay].

- Yilmaz, Fatih Mehmet. Hicri I-II. Astr Islam Toplumonda Sosjal Hajat u A ile Yaprs (Mukayeseli Bir Incelemr), Selçuk Üniversitesi Sosyal Bilimler Enstituisü, Konya 2002 [Dan: Doç. Dr. Bünyamin Solmaz].

- Yllmaz, Hulusi. Kentlesme Simecinde Aleuilik-Bektasilik, Süleyman Demirel Üniversitesi Sosyal Bilimler Enstitüsü, Isparta 1998 [Dan: Yrd. Doç. Dr. Ahmet Yilmaz Soyyer].

- Yilmaz, Nimet. Hz. A j̧e'nin Illk Mïsliöman Topluma Sosydojik Etkileri (Din Sosyolojisi A gssmdan Karizmatik T"̈p A rasttrmasi), Marmara Üniversitesi Sosyal Bilimler Enstitüsü, Istanbul 1998 [Dan: Prof. Dr. Yümni Sezen].

- Ylmazkan, Kadir. Prens Sebahaddini in Din ze Toplum Görüsü Erciyes Üniversitesi Sosyal Bilimler Enstitüsü, Kayseri 1994 [Dan: Prof. Dr. Ünver Günay]. 
- Yorgun, Mustafa. Mezheplenden Doğan Cemaatlesme, İstanbul Üniversitesi Sosyal Bilimler Enstitüsü, İstanbul 1990 [Dan: Prof. Dr. Amiran Kurtkan Bilgiseven].

b. Doktora Tezleri

- Akdoğan, Ali. Geleneksel Topluandan Modem Topluma Gegiste Dîrâ Hajat -Rize Il Mer. kezi Ömeğis, Ondokuz Mayss Üniversitesi Sosyal Bilimler Enstitüsü, Samsun 1999 [Dan: Yrd. Doç. Dr. Erkan Perşembe].

- Akgül, Mehmet. Tïnk Toplummm Değ̈rim Sïnecinde Din A nlaysslan, Selçuk Üniversitesi Sosyal Bilimler Enstitüsü, Konya 1996 [Dan: Yrd. Doç. Dr. Bünyamin Solmaz].

- Akyüz, Niyazi. Ankara'ran Bojazigi Sentinde Dini Hajat we Kentlilesme Üzerine Bir A rasttrma, Ankara Üniversitesi Sosyal Bilimler Enstituisü, Ankara 1994 [Dan: Prof. Dr. Münir Koştaş].

- Alperen, Abdullah. Çăgumz Islam Dïmasmanda Modemlesme Hareketleri we Tïnkine'deki Etkileri, Erciyes Üniversitesi Sosyal Bilimler Enstitüsü, Kayseri 1998 [Dan: Prof. Dr. Ünver Günay].

- Altıkardeş, İsmet. Din Eğtimimin Sosyal Yapr ze Sosyal Bütümlesme ile Illişkileri Üzenine Bir Inceleme, İstanbul Üniversitesi Sosyal Bilimler Enstitüsü, İstanbul 1991 [Dan: Prof. Dr. Enis Öksüz].

- Arslan, Mustafa. Tïak Popüler Dindarliğz Üzerine Sosyolojik Bir A rastrma, Enciyes Üniversitesi Sosyal Bilimler Enstitüsü, Kayseri 2002 [Dan: Prof. Dr. Ünver Günay].

- Arslantürk, Zeki. Tünk Sosyolöi Taribinde Nâimâ'nn Yeri ze Osmanlı Detetimin Çäkürs Sebeplern, Atatürk Üniversitesi Sosyal Bilimler Enstitüsü, Erzurum 1979 [Dan: Prof. Dr. Orhan Türkdoğan].

- Ayas, M. Rami. Tünkiye'de Ilk Tarikat Zümolesmeleri Üzerine Din Sosyolojisi A gsundan Bir A rastrma, Ankara 1969 [Din Sosyolojisi alanunda hazurlanan ilk doktora tezidir. Tez değerlendirme jünisinde: Ord. Prof. Dr. Hilmi Ziya Ülken, Prof. Dr. Mehmet Taplamacioğlu ve Prof. Dr. Neşet Çağatay yer almıştır].

- Aydemir, Salih. Seyh Mïrid iliskilerizle Belintermis Diri Cemâat sekli Olarak Tarikat Zümeleri (Sanlunfa'da Yasaman Kadiri Kolu Şesh Sodey ze Müridleri Üzerine Yapulan Bir Din Sosyolojisi A rastrmasi), Ankara Üniversitesi Sosyal Bilimler Enstitüsü, Ankara 1998 [Dan: Prof. Dr. Münir Koştaş].

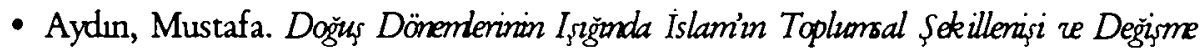
Dinamikleri, Selçuk Üniversitesi Sosyal Bilimler Enstitüsü, Konya 1991 [Dan: Prof. Dr. Mehmet Aydin]. 
- Bayyiğit, Mehmet. Ünizersite Gendiğinin Dini Inans, Tutum ze Dauramslan Üzerine Bir A rastıma, Uludağ Ǘniversitesi Sosyal Bilimler Enstitüsü, Bursa 1989 [Dan: Prof. Dr. Hüseyin Aydın].

- Bilgin, Vejdi. Sosjo-Kültïnel Şartlann Fıkhi Hükïomere E tkisi (Diri Hukukum Toplum sal Kainaklan Üzenine Sosjolojik Bir A rastrma), Ondokuz Mays Üniversitesi Sosyal Bilimler Enstitüsü, Samsun 2001 [Dan: Yrd. Doç. Dr. Erkan Perşembe].

- Bodur, Hüsnü Ezber. Dini İbjâ Hareketi Olarak Vabhâbiliğin Doğusus Gelismesi, Sosyo-Pditik we Ekonomik Neticderi, Atatürk Üniversitesi Sosyal Bilimler Enstitüsü, Erzurum 1986 [Dan: Prof. Dr. Ünver Günay].

- Ceran, Ahmet Şeref. XIII. Astrda Anadalu Selaklulannda Müslim Gayr-i Mïslim Mïnasebetleri, Selçuk Üniversitesi Sosyal Bilimler Enstitüsü, Konya 1992 [Dan: Prof. Dr. Mehmet Aydin].

- Cezayirli, Gülay. Ankara'da Bir Merleri Toplulüu -Din Sosjolojisi A gsmdan Bir A rastrma-, Ankara Üniversitesi Sosyal Bilimler Enstitüsü, Ankara 1996 [Dan: Prof. Dr. Münir Koştaş].

- Coşkun, Ali. Osmanli Dönemi Dini Kuntulus hareketleri Üzerine Sosjolojik Bir A rasttrma, Marmara Üniversitesi Sosyal Bilimler Enstitüsü, İstanbul 1996 [Dan: Prof. Dr. Yümni Sezen].

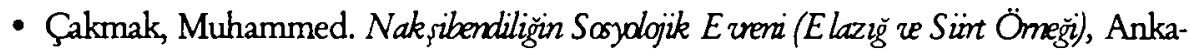
ra Üniversitesi Sosyal Bilimler Enstitüsü, Ankara 2004 [Dan: Prof. Dr. Münir Koştaş].

- Çelik, Celaleddin. Şebirlesme u Din-Koma Ömë̈i-, Erciyes Üniversitesi Sosyal Bilimler Enstitiusü, Kayseri 2000 [Dan: Prof. Dr. Ünver Günay].

- Cetinkaya, Hasan. Din Sosydojisi A gasindan A jetlerin Inass Sebepleri Üzerine Bir A rastorma, Ankara Üniversitesi Sosyal Bilimler Enstitüsü, Ankara 1982 [Dan: Prof. Dr. Mehmet Taplamacıoğlu].

- Çiftçi, Adil. Fazlur Rabmanim İlami Yenalikģ̧ğine Yomonlayra Bir Bakzs, Dokuz Eylül Üniversitesi Sosyal Bilimler Enstitüsü, Izmir 1998 [Dan: Prof. Dr. Erdoğan Fırat].

- Efe, Adem. Mesmitizet'ten Cumbronjet'e İslamalar ze Modemlesme, Uludağ Üniversitesi Sosyal Bilimler Enstitüiü, Bursa 2002 [Dan: Prof. Dr. Izzet Er].

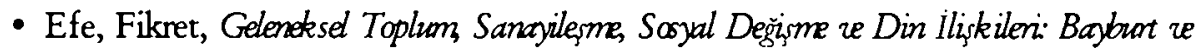
Kocaeli Ömekleri, Erciyes Üniversitesi Sosyal Bilimler Enstinüü, Kayseri 1997 [Dan: Prof. Dr. Ünver Günay].

- Er, İzzet. Sosjal Gelizme ue İslâm İstanbul Üniversitesi Sosyal Bilimler Enstituisü, 1984.

- Eren, Selim. Sasjolojik A gudan Ondu Yöresi A leriliğ̈ Ankara Üniversitesi Sosyal Bilimler Enstitüsü, Ankara 2002 [Dan: Prof. Dr. Münir Koştaş]. 
- Erten, Hayri. Koma Şer̈yje Sialleri Istğnda Âlenin Sosyo-Ekonomik ze Kültürel Yappst (XVIII. Yüzyllm İlk Yansı), Selçuk Üniversitesi Sosyal Bilimler Enstitüsü, Konya 2000 [Dan: Doç. Dr. Mehmet Bayyiğit].

- Karaman, Ramazan. Mersin'de Tanm we Sanayi Isçsi Kesimlerinde Dini Yasayusmon Karsslaşttrlmass, Selçuk Üniversitesi Sosyal Bilimler Enstitüsü, Konya 1992 [Dan: Yrd. Doç. Dr. Bünyamin Solmaz].

- Karaaslan, Halis. Milli Mücadele Döneminde Ís Isyanlarn Çikžnda Dini Faalijet ze Propagandanon Rä̈̈, Dokuz Eylül Üniversitesi Sosyal Bilimler Enstitüsü, İzmir 1997 [Dan: Prof. Dr. Erdoğan Fırat].

- Kaya, Kamil. Sosyolojik A qudan Tünkije'de Din-Detlet Ilijskileri ze Dijanet Islleri Baskanlı̆ğ İstanbul Üniversitesi Sosyal Bilimler Enstitüsü, İstanbul 1994 [Dan: Prof. Dr. Mustafa E. Erkal].

- Kayadibi, Fahri. Isrigre (Zïinh Kantonu)'de Tühk Issgilerin Sosyal Somonlan Üzerine Bir Inceleme, İstanbul Üniversitesi Sosyal Bilimler Enstitüsü, İstanbul 1994 [Dan: Doç. Dr. Zekeriya Beyaz].

- Keskin, Yahya Mustafa. 20. Yüzylda Tokat Illinin Sosyal ze Kültünd Yapus, İnönü Üniversitesi Sosyal Bilimler Enstitüsü, Malatya 1999 [Dan: Prof. Dr. Şaban Kuzgun].

- Kuliç, Ahmet Faruk. Tïnkine'de Din-Dedet Iliskilerinde Yönetici Segkinlerin Roü (19201960), Sakarya Üniversitesi Sosyal Bilimler Enstitüsü, Sakarya 1999 [Prof. Dr. Musa Taşdelen].

- Kirman, Mehmet Ali. Tünkije'de Bir Yeri Dîna Cemâat Ömeği Olarak Süleymanalık, Ankara Üniversitesi Sosyal Bilimler Enstitüsü, Ankara 2000 [Dan: Prof. Dr. Münir Koştaş].

- Kurt, Abdurrahman. Tanzîmat Döneminde Ailenin Sosjo-Ekonomik Yapisi (1835. 1876) Buosa Ömeği, Uludağ Üniversitesi Sosyal Bilimler Enstitüsü, Bursa 1994 [Dan: Doç. Dr. İzzet Er].

- Küçükeskici, Mustafa. Hz. Peygamber Döneminde Medine'nin Sosjal Yapiş Selçuk Üniversitesi Sosyal Bilimler Enstitüsü, Konya 1999 [Dan: Doç. Dr. Mehmet Bayyiğit].

- Nalçacıŏlu, İlhami. Neựebir'de Sosyal Tabakalasma ue Din Atatürk Üniversitesi Sosyal Bilimler Enstitüsü, Erzurum 1987 [Dan: Prof. Dr. Ünver Günay].

- Nart, Tahsin. Black Muslim Hareketinin Din Literatïn̈ndeki Yeri, Erciyes Üniversitesi Sosyal Bilimler Enstitüsü, Kayseri 1990 [Dan: Prof. Dr. Ünver Günay].

- Odabaşı, Fatma. Tünk Toplumonda Mïzik ue Eğlence A nlayzst ile Din Duggusu A rasar daki Ilişski (İstanbul Ömeği), Marmara Üniversitesi Sosyal Bilimler Enstitüsü, İstanbul 2001 [Dan: Prof. Dr. Yümni Sezen]. 
- Okumuş, Ejder. Osmanlı Dedetinde Tanzimat Dönemi Din-Dezlet Iliskisi, Marmara Üniversitesi Sosyal Bilimler Enstitüsü, İstanbul 1999 [Prof. Dr. Zeki Arslantürk].

- Özdoğan, Öznur. Dindanikla İlgili Bazı Faktörlerin Kendiri Gerceklestirme Dizeyine Etkisi, Ankara Üniversitesi Sosyal Bilimler Enstitüsü, Ankara 1995 [Dan: Prof. Dr. Münir Koştaş].

- Özterlemez, Ayşenur. Tünk Toplummanda DinzBäzü Illiskisi, Marmara Üniversitesi Sosyal Bilimler Enstitüsü, İstanbul 2001 [Dan: Prof. Dr. Yümni Sezen].

- Perşembe, Erkan. Toplumral Değḩme ue Din İliskilen (Ondu Ili Merkez Illesinin Iki Köyünde Karrslastrmalı Bir A rastrma), Ankara Üniversitesi Sosyal Bilimler Enstitüsü, Ankara 1991 [Dan: Prof. Dr. M. Rami Ayas].

- Polat, Fazh. Sosyal Deģ̧̆im ze Din Illiskisis Atatürk Üniversitesi Sosyal Bilimler Enstitüsü, Erzurum 2002 [Dan: Prof. Dr. Niyazi Usta].

- Sezen, Yümni. Dinin Dig̈er Sosyal Müesseseler Üzenindeki Tesinleri, İstanbul 1987.

- Sezgin, Abdülkadir. Tünkije'de Aleulike-Bektasilik Üzerine Sosjolojik Bir A rasttma İstanbul Üniversitesi Sosyal Bilimler Enstitüsü, İstanbul 1996 [Dan: Doç. Dr. Zekeriya Beyaz].

- Sinanoğlu, A. Faruk Genf Nïfusta Toplumbal Bütülesme ze Dirn Hajat 'E lbistan Öme Һ̆', Atatürk Üniversitesi Sosyal Bilimler Enstitüsü, Erzurum 2002 [Dan: Prof. Dr. Niyazi Usta].

- Solmaz, Bünyamin. Din Eğitimi ze Toplram Kalkurmass Selçuk Üniversitesi Sosyal Bilimler Enstitüsü, Konya 1985 [Dan: Doç. Dr. Beyza Bilgin].

- Soyyer, Ahmet Yilmaz. Sanlunfa'nn Kisas Beldesinde Bir Toplumsal ze Kültiönd Yapr Çö̈iomlemesi İstanbul Üniversitesi Sosyal Bilimler Enstitüsü, İstanbul 1992 [Dan: Doç. Dr. Durali Yilmaz].

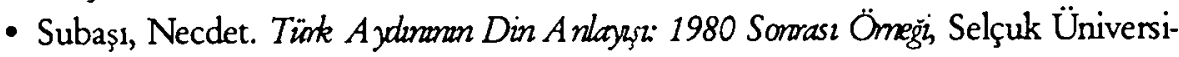
tesi Sosyal Bilimler Enstitüsü, Konya 1995 [Dan: Yrd. Doç. Dr. Bünyamin Solmaz].

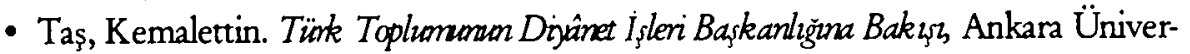
sitesi Sosyal Bilimler Enstitüsü, Ankara 2001 [Dan: Prof. Dr. Münir Koştaş].

- Tașğın, Ahmet. Dijarbakir ze Çevnesindeki Tïnkmen Alerilerinde Dirn Hajat, Ankara Üniversitesi Sosyal Bilimler Enstitüsü, Ankara 2003 [Dan: Prof. Dr. Münir Koştaş].

- Taştan, Abdulvahap. Gäs ze Din. Sosjo-Kültünd Değisme ue Kimlik Sonmu Çengeresinde

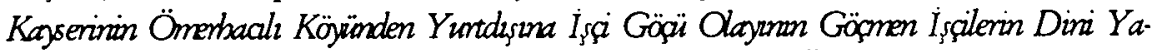
santularma E tkileri Üzerize Sosyolojzk Bir A rasttrma, Erciyes Üniversitesi Sosyal Bilimler Enstitüsü, Kayseri 1993 [Dan: Prof. Dr. Ünver Günay]. 
- Tatlilığlu, Durmuş. Dini Cemaatlenin Yappsal-Fonksinonel A nalizi (Kanseri ue A nkara İlleri Rufai Cemaati Ömeğ), Erciyes Üniversitesi Sosyal Bilimler Enstitüsü, Kayseri 1995 [Dan: Prof. Dr. Ünver Günay].

- Tekin, Mustafa. Tïktine'de A yden Kadenlara Göre Din ze Kaden, Selçuk Üniversitesi Sosyal Bilimler Enstitüsü, Konya 2003 [Dan: Doç. Dr. Mehmet Bayyiğit].

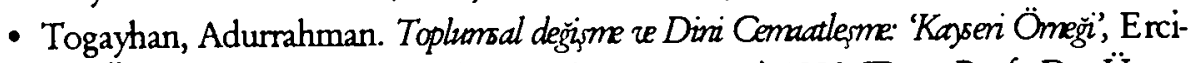
yes Üniversitesi Sosyal Bilimler Enstitüsü, Kayseri 1998 [Dan: Prof. Dr. Ünver Günay].

- Uçar, Ramazan. Aleri-Bektasi Geleneği Üzerine Sosjolojik Bir A rastrma (Abdal Musa Tekkesi Ömĕg), Ankara Üniversitesi Sosyal Bilimler Enstitüsü, Ankara 2003, [Dan: Prof. Dr. Münir Koştaş].

- Usta, Niyazi. Sosjal Hareketlilik ue Din Illizkisi-Samsum/Havza/Ilca Kasabast Ömeği-, Atatürk Üniversitesi Sosyal Bilimler Enstitüsü, Erzurum 1992 [Dan: Doç. Dr. Hüsnü Ezber Bodur].

- Yapic1, Asım. Genderde Dini Kalip Yargular (Sosjal Psikolojik Bir A rastrma), Erciyes Üniversitesi Sosyal Bilimler Enstitüsü, Kayseri 2002 [Dan: Prof. Dr. Ünver Günay].

\section{Sonuç ve Öneriler}

Ülkemizdeki ilahiyat fakültelerinde din sosyolojisi alanında hazırlanan yüksek lisans ve doktora tezlerinin genel istatistiksel dağlımına baktığımızda, son yıllarda, özellikle 1995 sonrası, tamamlanan tezlerin sayssında hızlı bir artış görülmektedir. Bu durum, doksanl ylllarda ilahiyat fakültelerinin saylanndaki artışın doğal bir sonucu olarak değerlendirilebilir. Aynca, ilahiyat disiplinleri içerisinde din bilimlerine ilginin her geçen gün artması, din sosyolojisine yönelik ilgi artışın da beraberinde getirmiştir. Özellikle son on ylda hazırlanan tezler içerisinde alan araşturmalanının sayssında periyodik bir artış gözlenmektedir. Şerif Mardin'in ifadesiyle dinin kitabi ya da teorik boyutlanndan ziyade "günümüz Türkiye'sinde İslamiyet'in sokaktaki adamın fikri kaliplanın etkileme mekanizmasını" 2 anlama ve açıklama gayreti içerisinde olan ampirik din sosyolojisi araştırmalan, ülkemizin dini coğrafyasınun tespiti ve tanunması açısından değerli bilgiler ve öneriler ihtiva etmektedir. Bu çerçevede, ülkemizde din hizmetlerinin yürütücüsü konumundaki Diyanet İşleri Başkanlğ'nin yan sıra, Nakşibendilik, Halvetilik, Mevlevilik ve Kadirilik gibi tarikat gruplan; Süleymancllk, Nurculuk ve Aczimendilik gibi dini gruplar ya da yeni dini hareketler, Alevi-Bektaşiler, Abdallar ve Caferiler gibi heterodoks

${ }^{2}$ Şerif Mandin, Din ze Idedgi (9. Basku), iletişim Yay., İst., 2000, s. 67. 
gruplar hakkında gerek yüksek lisans gerekse doktora düzeyinde kapsamlı araşturmalar gerçekleştirilmektedir. Aynca, sosyo-kültürel değişme, gelişme, farklilaşma ve bütünleşme ile din arasındaki karşllklı etkileşimlerin yakın dönem dini-sosyal tarihimizdeki örnekleri ve özellikle Tanzimat, Meşrutiyet ve Cumhuriyet dönemlerinin sosyo-kültürel mirası din sosyologlannın araştırma konulan arasındadır. Bu araştırmalann ortaya çıkardığı sonuçlann başta Diyanet İşleri Başkanlığı olmak üzere ülkemizdeki dini hizmet birimlerinin hizmet politikalan belirlenirken göz önünde bulundurulması, hizmet kalitesinin yükseltilmesine ciddi katkılar sağlayacaktır. Aynca, özellikle Diyanet İşleri Başkanlığı'nın din bilimciler tarafından hazırlanacak projelere sağlayacağı destek, kurumlar arası işbirliğinin yanı sıra, ülkemizde yaşayan farklı İslam anlayışlannın din bilimsel metotlarla incelenmesi ve sağlıklı sonuçlara ulaşıması açısından kayda değer öneme sahiptir. 